\title{
INDONESIAN EXPERIENCE IN DEALING WITH TRADEMARK LAW: CASE STUDY OF BATIK SMES
}

\author{
Agus Sardjono \\ Brian Amy Prastyo \\ Desrezka Gunti Larasati
}

\begin{abstract}
This research aims to observe whether the Trademark Law can contribute to protect Indonesia's batik business, particularly for the small-medium enterprises who produce and sell batik products ("Batik SMEs"). The individual trademark system has not been successful to support the batik SMEs' business. However, the fact that those SMEs gather in a community, organization, or kinships bring potentials for the development of collective trademarks, which can address the problems that individual trademark cannot anticipate. This research finds that, in order to anticipate the free-trade 'attack,' i.e. imported textiles with batik patterns/motifs; Indonesian batik SMEs need to be nurtured and encouraged to register their own collective trademarks, and to build their branding infrastructure, through local batik community's standardization, and collective batik labeling. This recommendation is also proposed considering the government's ineffective policy on Batikmark. This research will take samples of Batik SMEs in several areas, namely Yogyakarta, Pekalongan, Solo, and Jakarta. Those areas have been recalled as some of the centers for Batik production and trading activities. This research is conducted through combining the quantitative and qualitative-empirical methods. Data are collected through literature studies, interviews, as well as questionnaires, including site visits and discussions with the SMEs in those areas.
\end{abstract}

Keywords: trademark law, batikmark, small-medium enterprises

\section{Introduction}

Batik Indonesia not only possesses commercial value as a business, but also an authentic cultural value. Protecting Indonesia's batik means as protecting both the commercial and cultural value. Batik Indonesia is also diverse. Each batik community in each local area can possess its own quality, characteristic, and reputation, which all of them are cultural, and commercial. Batik Indonesia was acknowledged by the United Nations Educational, Scientific, and Cultural Organization (UNESCO) as an intangible cultural heritage in 2009. It was acknowledged that Indonesian batik culture represents three domains as an intangible cultural heritage: (1) oral tradition, (2) social custom, and (3) traditional handcrafts. The field study and research of batik showed that members of batik communities in various areas have engaged in batik culture and productions for $3-4$ generations or more. The cultural traditions have been passed on by oral means from their family members. Furthermore, batik 
cloths and/or clothes have also become part of societies' cultural outfits either as daily dress or in special or distinct events, such as marriage, $7^{\text {th }}$ month of a mother's pregnancy, or being used as slings for carrying babies. For each use on such events, different pattern of batik cloth is applied, in which each of the pattern has its own symbol, meaning, and philosophy that correlates with its aim of use. Besides, the cloth is also designed for particular functions, such as sarong, which is used to cover body parts from waist to the feet, or kemben, a piece of cloth which is used to cover the women's chest ${ }^{1}$. The batik cloths, as well as the tools used, are made by hands, therefore Batik culture involves distinguished craftmanships ${ }^{2}$. For instance, the craftmanship's abilities are not only on the creation of patterns/motifs of batik cloth, but also in the coloring quality and technique ${ }^{3}$.

In 2012, Indonesia's domestic markets were filled up by vast imported 'batik' products from other countries. Those imported products, which local batik communities mention as (only) 'textille with batik pattern/motifs' came from China and Malaysia. Data from Indonesia's Center of Statistic Agency (Badan Pusat Statistik - BPS) stated that 1.037 tons of imported 'batik' from China entered Indonesia's markets in $2012^{4}$. To this date, many imported 'batik' can still be found in the markets. This phenomenon had made some of the local batik SMEs worried, since the imported 'batik' are being sold at cheap prices, and can be produced quickly in massive numbers 5 . Their concerns are reasonable, since the consumers can hardly differentiate between the local batik and the imported ones. Consumers or buyers tend to choose the products with cheaper prices. Since the imported 'batik' are cheaper than the local products, many of the consumers then bought them rather than the local ones. This has diminished local batik's selling value because in order to compete with those imported 'batik', the local SMEs have to lower down their selling prices. This is an irony since the imported 'batik' and the local batik

${ }^{1}$ Inger Mccabe, Elliot, Batik - Fabled Cloth of Java (Periplus Editions (HK) Ltd., 2004), 33-34.

${ }^{2}$ See Nomination for Inscription on the Representative List in 2009 (Reference No. 00170) - Indonesian Batik, Intergovenrmental Committee for the Safeguarding of the Intangible Cultural Heritage, Fourth Session, Abu Dhabi, United Arab Emirates, 28 September to 2 October 2009, the United Nations Educational, Scientific, and Cultural Organization (UNESCO).

${ }^{3}$ The quality of batik's colors can be assessed from how fast the colors infiltrate into the cloth, and whether the colors are easily become dull or otherwise. Such traditional knowledge and technique on color-dyeing, including the materials needed and used for colors, are passed on from one craftman/ craftwoman to his/her following generations. The famous four colors of classical batik are indigo which results in blue colors, mengkudu from morinda citrifolia for red colors, tegerang from cudriana javanesis for yellow color, and soga from pelthophorum ferrungineum which results in chocolate/old yellow color. See MCCABE, see note 1,56 .

${ }^{4}$ See The Indonesian Way, Impor Batik dari China Mencapai Rp 285 Miliar (Imported Batik from China Reached IDR 285 billions), http://www.theindonesianway.com/impor-batik-dari-china-mencapairp-285-miliar/ (visited June 26, 2013). The chairman of Indonesia's Textille Association (Asosiasi Pertekstilan Indonesia), Ade Sudrajat, stated that the 'attack' of imported 'textille with batik patterns/motifs' to Indonesia's local markets have happened since 4 years ago. Such imported products are being sold at cheap prices; weaken the competitive power of local batik products, which generally have higher prices than the imported ones.

${ }^{5}$ See Gina Nur Mafthuhah, Gubernur Jateng Keluhkan Serbuan Batik Impor China (visited June 25th, 2013), http://jakarta.okezone.com/read/2011/10/03/320/510056/gubernur-jateng-keluhkanserbuan-batik-impor-china; and See Batik China dan Jiran Ganggu Daya Saing Produk Lokal (visited June 25th, 2013), http://ekbis.rmol.co/read/2011/08/03/35131/Batik-China-\&-Jiran-Ganggu-Daya-SaingProduk-Lokal-. This capability of imported 'batik' traders is also confirmed by the SMEs that are being interviewed during this study. 
products have an essential difference. The difference is that the imported 'batik' products are not Batik Indonesia. Just as the local batik SMEs stated, those imported ones are only 'textille with batik pattern/motifs' and they do not possess the cultural characteristic and qualities that batik of Indonesia have.

The imported 'batik' can have similar pattern/motifs with local batik, however they are made using machines. The patterns/motifs are being printed into the cloths; making them similar to other mass textile products of garment industry. Batik cloths are made through traditional craftmanships, by applying dots and lines of hot wax (refers to malam in Bahasa Indonesia's term) to the cloth using a copper pen-like instrument named canting tulis, or copper stamps named canting cap, as a resist to hand-dyeing later removed by boling and/or scrapping ${ }^{6}$. This process is repeated for each color that will be applied into the cloth. The more the color combinations, the more the application of hot wax and hand-dyeing process are repeated. Therefore, cloths with batik patterns/motif that were not made through such process cannot be considered as batik, and the traders or companies making such printed textilles of batik patterns/motif should not be using the term 'batik' to market their products in Indonesia ${ }^{7}$. Batik cloth which is made using canting tulis (pen-like instrument) is called batik tulis, whereas those made using canting cap (stamp-like instrument) is called batik cap. The two products are those which have been considered as Batik Indonesia.

The local SMEs from well-known areas of batik productions and trading centers should endure the impact of imported 'batik.' Only small group of consumers understand the difference between batik tulis, batik cap and imported 'batik,' and such small numbers keep buying the real Indonesian batik's products. For the rest of the consumers, they think that they have already bought and wore batik, while in fact the products they bought are actually those of imported ones. The attack of imported 'batik', then, not only decreases the economic income and lessen the potential consumers of local batik SMEs, but also it threathens the preservation of batik cultural and traditional value. In this context, the utilization of trademarks may become one solution to protect the local batik products, as well as strengthening the position of batik SMEs while competing with traders of imported 'batik.' In this context, the use of trademarks can help indicating local batik SMEs products as compared with the imported 'batik.' Trademarks can indicate the source of batik products, whether coming from local SMEs or from foreign companies. Further, trademarks then can also be used to indicate/distinguish which products are batik of Indonesia, or which are only imported textiles printed with batik patterns/motifs.

From the perspective of consumers, the use of trademarks as instruments to mark local batik and imported 'batik' can help them understand the essential

${ }^{6}$ See Nomination for Inscription of Batik Indonesia, see note 2.

${ }^{7}$ To summarize, the process of making batik cloth starts with drawing patterns (mola), applying hot wax into the patterns with various shapes or motifs using canting into each side of the cloth, applying hot wax into the parts of cloth which will not be colored, hand-dyeing of cloth for applying colors, removing hot wax from the parts that will be hand-dyed into other colors, applying hot wax into the parts that will keep the original or first dyed-color, then boiling the dyed-cloth to remove all its hot wax. See Drs. Hamzuri, Batik Klasik (Djambatan, 1989), 16-17, and see Batik Tulis, Forum Pengembangan Kampung Batik Laweyan, http://www.kampoenglaweyan.com, (visited July 17th, 2013). 
difference between the two, and make them aware of the cultural traditions surrounding batik. Batik cloths characteristic of one area may be different with the others. Among the six areas that UNESCO has mentioned as having concentrations of batik culture ${ }^{8}$ : DKI Jakarta, Cirebon, Madura, Pekalongan, Surakarta, and Yogyakarta, each of them has different characteristics. Even within the many numbers of batik SMEs or batik craftsmen/craftswomen in one area, particular character of each SME or craftsmen/craftswomen can be identified. Aside from such individual character, the uniqueness or specific quality can also be drawn communally as a community or kinship of batik craftsmen/craftswomen in one particular area ${ }^{9}$. Therefore, the trademarks not only can be utilized individually by such SMEs or craftsmen/craftswomen, but also as collective trademarks of certain community, kinships, or organizations of batik SMEs.

The research analyzes batik SMEs' current conditions and expectations in regards to their business and batik culture continuance. From the findings, it could be stated that individual trademarks system has not been successful to anticipate the free-trade attacks and support the business; yet, the local batik SMEs can still develop and utilize the trademark collectively considering their communal value and local elements. The government's policy on Batikmark, which is aimed to indicate batik of Indonesia, seemingly has not been effective to support the SMEs' business. The research took samples of batik SMEs residing in batik trading centers of several areas: Yogyakarta, Pekalongan, and Solo. By taking into account the characteristics and needs of each community, as well as its collective potentials; the collective trademarks can be utilized to support batik SMEs in competition with foreigners in free-trade markets ${ }^{10}$. In order to achive such objective, this study propose the recommendations to nurture and encourage batik SMEs to register their collective trademarks, as well as to build their branding infrastructures, through local batik community's standardization, and collective batik labeling.

\section{Batik SMEs in Indonesia}

Based on its historical backgrounds, batik of Indonesia can be divided into several types: (1) Batik Kraton Jawa or Batik Jawa Klasik (Classical Javanese Batik), and (2) Batik Pesisir (Coastal Batik) ${ }^{11}$. The first type, Batik Kraton Jawa can also be called as inland batik (batik pedalaman), and

\footnotetext{
${ }^{8}$ See UNESCO (United Nations Educational, Scientific and Cultural Organizations), Indonesian Batik, http://www.unesco.org/culture/ich/RL/00170 (visited June 25th, 2013) and see note 2.

${ }^{9}$ This potential of collective trademark utilization by particular group or community is also based on prior art research which indicates a living value of communality within Indonesian societies. See Sardjono, Agus, et.al., Pemanfaatan Hak Kekayaan Intelektual Oleh Pengusaha Kerajinan Mutiara di Lombok dan Kerajinan Rotan di Amuntai (Intellectual Property Rights Utilization by Pearl Craftsmen in Lombok, and Rattan Handicrafts in Amuntai), Primary Grant Report of University of Indonesia's Leading Research Year 2012, Faculty of Law, University of Indonesia; and see Sardjono, Agus, Membangun Sinergi dalam Mengembangkan Industri Kreatif: Suatu Pendekatan Hukum (Empowering Synergy to Develop the Creative Industry: A Legal Approach), Final Report of National Strategic Research Grant Year 2009.

${ }^{10}$ One solution being addressed to protect local SMEs is by increasing the import tarrif for imported goods, including those of 'textille with batik patterns/motif', yet the Indonesia has committed to join the free-trade environment, making the proposed policy barely visible.

${ }^{11}$ See Evi Steelyana, Batik, A Beautiful Cultural Heritage that Preserve Culture and Support Economic Development in Indonesia (Bina Nusantara University), www.ssrn.com, (visited July 9th, 2013), 6.
} 
represents the artistic and esthetique quality of Javanese culture. This batik uses soil-nuance colors such as black, chocolate, and old yellow (or 'soga'), with (sometimes) white background. The style of its pattern is organized/ orderly and geometrical. The symbols or motifs in Batik Kraton's patterns contain philosophical meanings, and during old times, not all people can wear batik cloth that has certain symbols or motifs. The Javanese Court's (Kraton Jawa) family members were the ones that can wear batik cloth having those particular symbols or motifs. The two cities in Java having the court's system and culture are Yogyakarta and Solo (or Surakarta, historically Surakarta's Court - Kasunanan Surakarta). It has been said that inland batik were developed by the communities in these two areas since the court's system was born. In Solo, two areas famous for their batik productions are Laweyan and Kauman, while Pasar Klewer is the traditional market that has been wellknown as the center for batik trading activities in the city. Soga colors become the main characteristic of batik products that come from these areas. While in Yogyakarta (historically Yogyakarta's Court - Kasultanan Yogyakarta), the batik products are characterized by the use of white background. Some of the areas being the center for batik productions are Imogiri and Tamansari, with famous traditional market in Malioboro area named Pasar Beringharjo (Beringharjo Market), and well-known batik store Mirota. Yogyakarta and Solo's batik have similarities in regards to the symbols and motifs/patterns of their batik, yet they can be differentiated from the intensity of colors they use, thus making each of the area having its own batik characteristic.

Batik Pesisir (Coastal Batik) are produced by several areas residing around the north cost of Java and Madura. The coastal batik's designs, patterns/motifs, and coloring styles got influences from various cultures, namely European, Chinese, and Arabian's. This is because historically the north coast areas were used to be part of trading activities with foreigners. The characteristics of this type of batik are in the variation of motifs and use of bright colors. For instance, patterns of coastal batik cloths may contain Chinese-influenced motifs in shapes of phoenix, clouds, dragon, or European's influence shapes as flower bouquets, and so on. One of the areas in Central Java which is famous for its coastal batik productions is Pekalongan. Pekalongan's batik is much influence by European and Chinese motifs.

Not only that each area produces different batik with particular characteristics, but also within the SMEs in one area, each can have identity, quality, and character that are different with each other. For instance, such different quality can be seen from the coloring intensity or use of the natural or chemical dyes, as well as the creativity and artistical creation of batik's patterns, and how they combine each motif into an organized or variative nuance of batik cloth. The inheritance of cultural traditions from the older family members seems to influence their traditional craftmanships and creativity of producing batik. In trading activities, such particular qualities or characters may add to the commercial value of their products, including create a good image or reputation in the eye of consumers.

\section{A. The Nature of Batik SMEs' Business}

As aforementioned, the research takes samples of batik SMEs in several areas. Those particular areas are Yogyakarta city and Giriloyo in Bantul, 
special region of Yogyakarta; Kauman in Pekalongan; Laweyan in Solo, and the SMEs having outlets in Thamrin City, one of trading malls in DKI Jakarta. The village of Laweyan, or in Bahasa Indonesia Kampung Batik Laweyan, in Solo (Surakarta), Central Java, is a historical area of trading activities, with batik as one of its well-known commodities. The area becomes the home of batik traders for generations until now ${ }^{12}$. Laweyan's batik SMEs produce many types of batik products, namely batik tulis, batik cap, batik printing, including screen-printing, or combination of all of them. According to the data of 2011 obtained from the village's organization, Forum Pengembangan Kampung Batik Laweyan (or FPKBL), currently there are 92 batik SMEs in the area, which focus on: batik-processing (workshops), garment production, and showrooms or stores. Some of them may focus on all the fields, i.e. from batikprocessing to showroom, but there are also those who focus only on one or two of them.

Yogyakarta city and Giriloyo are situated in the Special Region of Yogyakarta. Giriloyo is part of Bantul region. Yogyakarta areas also have historical development on batik, especially when batik becomes Yogyakarta's court members' outfits, and later, the society's daily dress even though they only can wear certain patterns /motifs. Yogyakarta city's batik products include batik tulis, batik cap, batik printing, or combination of them, while Giriloyo is famous for its batik tulis and batik cap production. Moreover, Pekalongan is famous for its coastal batik for generations, and the craftswomen/craftsmen are known to have the flexibility in adopting foreign influences, and apply them to create their own batik products. As examples, the shape of a motif called Jlamprang is influenced by India and Arab, while Encim and Klenengan motif were influenced by the Chinese ${ }^{13}$. The SMEs in Pekalongan sell the products through showrooms around the village or residence areas. One of the centers for batik trading in Pekalongan is Pasar Grosir Setono, which is established since $2000^{14}$, while some of centers for batik production are Kauman, Jenggot, and Tegalrejo ${ }^{15}$. According to the data of 2012 from the Regional Office of Industry, Trade, Cooperatives, and Small-Medium Enterprises of Pekalongan, there are 27 batik SMEs having their trademarks registered.

In regards to the SMEs structure, Teruo Sekimoto ${ }^{16}$ who once made a research at batik communities in several areas in Indonesia, mention that the business scale of batik craftsmen/craftswomen who produce batik is usually in the level of home industry, where all members of a batik craftsmanship family do all the production process by themselves. In this level, their houses become their workshops as well as showrooms. Those who want to buy their batik clothes then have to visit their houses directly. While at the higher level, batik SMEs may have bigger workshop or even factory for batik productions and or without its batik garment-processing factory, paid craftsmen/ craftswomen, and their own dedicated showrooms or batik stores to sell the

12 See Forum Pengembangan Kampung Batik Laweyan, see note 7.

${ }^{13}$ See Sejarah Singkat, City of Pekalongan's Government Website, http://www.pekalongankota. go.id, (visited July 17th, 2013).

${ }^{14}$ Sekimoto, Teruo, et.al., Handicrafts and Socio-Cultural Change: A Study of Batik Making in Cirebon and Pekalongan (Centre for Japanese Studies, University of Indonesia, 2003) 19-22.

${ }^{15}$ See Sentra Industri, Office of Industry, Trade, Cooperatives, and Small-Medium Enterprises of Pekalongan city, http://perindagkop.pekalongankota.go.id/, (visited July 17th, 2013).

${ }^{16}$ See SEKIMOTO, see note $14,9$. 
products. These SMEs sometimes may also order batik products from the home industries, which then they sell through their showrooms or stores. The batik craftsmen/craftswomen working in those SMEs are usually hired from various areas of Java, which have been well-known for their batik qualities. The number of workers in each SME may vary from less than 100 people to above it. However, in the level of home industry, it is basically between $20-30$ workers per workshop.

Similar to Sekimoto's findings, a prior art research on Indonesian SMEs ${ }^{17}$ drew conclusion that the SMEs may be categorized into: the craftsmen/ craftswomen having workshops, the craftsmen/craftswomen hired as workers in workshops, the craftsmen/craftswomen having workshops and showrooms, showrooms/stores having their own workshops and paid workers, and solely showrooms/stores who order products from workshops or particular craftsmen/craftswomen. In relation to such categorization, our field findings ${ }^{18}$ in Yogyakarta city; Giriloyo in Bantul; Kauman in Pekalongan; and Laweyan in Solo, point-out certain conclusions as followed:

a. There are SMEs consisting only a number of craftswomen/craftsmen producing batik at their houses as workshops, or in a joined workshop. Those batik craftswomen/craftsmen are either members of batik culture families, which in this case they continue the family's batik business, or they gather in particular kinships working together in a joined workshop, and sell their batik products through a joined showroom. The batik culture families may have particular family's workshops and sometimes also showrooms (at their houses or at particular location/trading center), with varied scale from micro to medium size. These SMEs may also sell the products through other showrooms, or receive orders from traders or consumers directly.

b. There are also particular numbers of big SMEs which have a sophisticated factory or workshops to produce batik cloth and clothings, as well as dedicated showrooms. Usually they have already earned good reputation among the others and may have a recognized - if not well-known, trademark.

c. There are also particular SMEs focusing on batik garment industry. They produce any kind of clothings made from original batik cloths. The SMEs who already have sophisticated factory or workshops for batik cloths production, usually also produce the clothings. However, there are also SMEs who are not making batik cloths, and they need to order them from other SMEs' workshops. In this case, their main business is only to produce clothings (garment-processing) from pieces of batik cloths. These SMEs may also have dedicated showrooms, or merely as the producers of batik clothings, and supply them to other SMEs based on partnerships or orders.

d. There are also SMEs who only take roles as batik traders and/or showrooms. They order batik products from various workshops or smaller SMEs, and sell them through showrooms or Internet's sites.

e. Based on the samples we studied, majority of SMEs in Giriloyo, Bantul are those included in point (a) above, while in Yogyakarta city, the SMEs

${ }^{17}$ See SARDJONO, Intellectual Property Rights Utilization.., see note 7.

${ }^{18}$ The field studies are conducted through interviews with respondents or informants, discussions, and questionnaires in each of the respective area. 
are varied between the above four points ${ }^{19}$. In Kauman, Pekalongan, it can be said that generally the SMEs' structure is a mixed of point (a) and (c), in which they have already owned their small/medium-sized family's workshops and showrooms, and not only producing cloths, but also clothings. While in Laweyan, Solo, there are SMEs who only involve in the production of batik cloths or garment (clothing), but there are also those who have their own workshops and showrooms, either as producing batik cloth or clothing ${ }^{20}$, including some on batik crafts.

Table 1: Categorization of Batik SMES

\begin{tabular}{|c|c|c|}
\hline Area & Business Activities & Community Structure \\
\hline $\begin{array}{l}\text { Yogyakarta } \\
\text { City }\end{array}$ & $\begin{array}{l}\text { 1. Family business with } \\
\text { workshops, supplying } \\
\text { products to showrooms/ } \\
\text { stores } \\
\text { 2. Family business with } \\
\text { workshops and dedicated } \\
\text { showrooms; producing } \\
\text { and selling batik } \\
\text { 3. Showrooms/stores only }\end{array}$ & $\begin{array}{l}\text { Individual family business with or } \\
\text { without paid workers as batik craft- } \\
\text { women / craftmen in workshops, } \\
\text { and paid or non-paid (family mem- } \\
\text { bers) administrators / staff in show- } \\
\text { rooms }\end{array}$ \\
\hline $\begin{array}{l}\text { Giriloyo, } \\
\text { Bantul, DIY } \\
\text { Yogyakarta }\end{array}$ & $\begin{array}{l}\text { Small business with work- } \\
\text { shop and showroom at their } \\
\text { houses }\end{array}$ & $\begin{array}{l}\text { 1. Residing in one village } \\
\text { 2. Small family business' workshop } \\
\text { and showroom located in the } \\
\text { house } \\
\text { 3. Kinships of craftwomen / craft- } \\
\text { men working together in a joined } \\
\text { workshop, and sell the products } \\
\text { through a joined showroom at } \\
\text { particular houses } \\
\text { 4. Gather in batik village's organiza- } \\
\text { tion/kinship }\end{array}$ \\
\hline $\begin{array}{l}\text { Kauman, } \\
\text { Pekalongan }\end{array}$ & $\begin{array}{l}\text { Small to medium-sized busi- } \\
\text { ness with workshops and } \\
\text { showrooms at their houses }\end{array}$ & $\begin{array}{l}\text { 1. Residing in one village } \\
\text { 2. Family business with workshop } \\
\text { and showroom located at their } \\
\text { houses } \\
\text { 3. Gather in batik village's organiza- } \\
\text { tion/kinship }\end{array}$ \\
\hline
\end{tabular}

${ }^{19}$ One example of a well-known batik store in Yogyakarta city is Mirota. According to its manager, Mirota does not produce its batik products by itself; rather, it orders the products from various workshops in Yogyakarta area.

${ }^{20}$ An example of Laweyan's batik SMEs is Batik Mahkota Laweyan, which is owned by the chairman of FPKBL, Ir. Alpha Febela Priyatmono. 


\begin{tabular}{|c|c|c|}
\hline Laweyan, Solo & $\begin{array}{l}\text { Small to medium-sized busi- } \\
\text { ness with varied activities: } \\
\text { 1. Workshops and show- } \\
\text { rooms at their houses } \\
\text { 2. Workshops only; provide } \\
\text { cloths to be sold either } \\
\text { in its original form, or as } \\
\text { the materials for clothing } \\
\text { productions } \\
\text { 3. Clothing production from } \\
\text { batik cloths (garment- } \\
\text { processed), with or with- } \\
\text { out showrooms } \\
\text { 4. Showrooms only, selling } \\
\text { various kinds of batik } \\
\text { cloths/clothing } \\
\text { 5. Workshops and cloth- } \\
\text { ing productions, with or } \\
\text { without showrooms } \\
\text { 6. Batik handicrafts }\end{array}$ & $\begin{array}{l}\text { 1. Residing in one village } \\
\text { 2. Family business with workshop } \\
\text { and showroom located at their } \\
\text { houses } \\
\text { 3. Gathered in batik village's orga- } \\
\text { nization (FPKBL), which serves } \\
\text { for Laweyan's development as a } \\
\text { batik village. }\end{array}$ \\
\hline
\end{tabular}

*This categorization is according to our research findings on batik SMEs' samples residing in Yogyakarta, Giriloyo, Kauman, and Laweyan.

An important similarity can be observed from the above situations in the three areas. Generally the SMEs gather in a particular organization or kinship. This fact brings potential for community's optimalization as an organization or kinship of batik SMEs to develop the business of batik, either economically or culturally. As an organization or kinships, batik SMEs can cooperate with each other to build their products' branding infrastructures; things they can hardly execute if being individually.

\section{B. The Attitude of Batik SMEs in Yogyakarta, Pekalongan, and Solo in Dealing with the Imported 'Batik'}

As aforementioned, cheap prices of imported 'batik' products have put them in preferable positions in the eye of consumers. In dealing with this condition, Indonesia's local batik SMEs' attitudes reflect varied perspectives, yet somehow similar to each other. They oppose the imported textiles and confront them as 'non-batik' products, but also began producing printed textiles with batik patterns/motifs, which they name as'batik printing.' The reason of this attitude is in order to keep profiting from the business. Since the imported 'batik' products are being sold at cheap prices, this made the local batik SMEs then have to lower down the prices of their batik products, so that they can keep competing in the market. However, high prices for materials of batik, such as mori cloths and longer process for finishing the products (since they are not using machines), made the SMEs can gain only small amount of profit from the business if they sell them in lower price. Therefore, they began to diversify their productions to include also 'batik printing,' considering its low cost of productions. Along the way they start to develop the production process by combining printed batik with the traditional ones. One of batik 
experts from Pekalongan, Zahir Widadi, mentions that the SMEs cannot avoid the development of technology in producing batik. Even so, the SMEs still have to honor the original batik culture and traditions. In this context, to strengthen their positions while competing in the markets, innovation and adaptation to the new technology of production may be necessary, yet the implementation should not diminish the original and philosophical value of batik culture and traditions.

It can be found, then, local batik SMEs who are still focusing on traditional batik (batik tulis and batik cap) productions, as well as those who have already shifted their business to include 'batik printing.' It can be found also SMEs who produce combinations of batik cap and/or batik tulis with batik printing. Those SMEs who also produce batik printing textiles do realize that those printings are not batik. However, Zahir Widadi mentioned that the process of batik printing production may also involve the use of hot wax (malam), so that it becomes a combination of traditional and modern batik productions. This raises a discourse of modern batik technique inclusion into batik culture, which means that at one point, printed textiles with batik motifs/patterns which also use malam during the process, may be included as batik products, or at the least, modern batik products. Yet it also contains risk of diminishing the original value of batik culture.

Apart from the SMEs changing attitude to produce batik printing, some of them also try to communicate and explain the difference between traditional batik and printed-batik textiles to consumers who want to buy the products, usually by providing samples ${ }^{21}$. This aims to provide understanding for consumers, so that they can choose either to buy the traditional batik, or the non-batik. In this case, if the consumers bought printed-batik which was far cheaper than the traditional ones, they could know that the products they bought are not batik. Furthermore, some SMEs also stated that each type of batik products has its own consumers. The traditional (batik tulis and cap) batik has different market with batik printing. Therefore even though the sale's numbers are decreasing, there are still certain consumers who are aware on the different quality and value of traditional batik, and so keep buying the traditional products. Considering its different market, the SMEs then can keep producing traditional batik, even though the amount may be less than the amount of batik printing products. Even so, there are particular SMEs which refuse to produce batik printing, and (still) only produce traditional batik products.

${ }^{21}$ Some SMEs having outlets in Thamrin City, Jakarta mention that they usually explain to the consumers the difference between traditional batik and batik printing, and they also provide each of the product's samples. 
Table 2: SMEs Batik Products in Yogyakarta, Solo, Pekalongan, and Jakarta

\begin{tabular}{|l|l|}
\hline \multicolumn{1}{|c|}{ Areas } & \multicolumn{1}{c|}{ Types of Batik Products } \\
\hline Yogyakarta city & $\begin{array}{l}\text { Batik cap (stamped batik), small number of batik tulis } \\
\text { (written batik), combination of stamped and written, } \\
\text { combination of traditional and batik printing }\end{array}$ \\
\hline Giriloyo, Bantul & $\begin{array}{l}\text { Batik cap (stamped batik), batik tulis (written batik), } \\
\text { combination of stamped and written }\end{array}$ \\
\hline Kauman, Pekalongan & $\begin{array}{l}\text { Batik cap (stamped batik), batik tulis (written batik), } \\
\text { combination of stamped and written, variety of (com- } \\
\text { bined / non-combined) batik printing }\end{array}$ \\
\hline Laweyan, Solo & $\begin{array}{l}\text { Batik cap (stamped batik), batik tulis (written batik), } \\
\text { combination of stamped and written, variety of (com- } \\
\text { bined / non-combined) batik printing }\end{array}$ \\
\hline $\begin{array}{l}\text { Thamrin City, Jakarta } \\
\text { (Batik Products' Stores) }\end{array}$ & $\begin{array}{l}\text { Majority of Batik cap (stamped batik), certain number of } \\
\text { combined batik printing, small number of batik printing }\end{array}$ \\
\hline
\end{tabular}

*This categorization is according to our research findings on batik SMEs' samples residing in those respective areas.

Moreover, the SMEs also share their perspective regarding the preference of batik printing by consumers. For its traditional and complicated process of batik tulis and batik cap, it made the products having higher prices than batik printing. Reachable prices of batik printing actually give opportunity for the people with medium and low economy capabilities to buy and wear batik-related products. Surely from the point of view of SMEs or more knowledgeable and prosper people from middle and high economy classes, those batik printing are not batik. However, for the middle and low economy class people, they can feel like they are dressed in batik, even though it is actually made of printed-textille. In this context, by also producing batik printing, the SMEs think that they can fulfill the market demand of middle and low economy class people for batik-related products.

\section{III.Trademarks Utilization by Batik SMEs in Indonesia}

As aforementioned, the use of trademarks has particular functions: (1) Serve as an identification mark to distinguish local batik products with those of imported textiles, and (2) serve as a distinguishing mark for each of batik SMEs in correlation with their quality and characteristic of batik products. The trademarks then can support the SMEs promotion and marketing of their products, including while competing with imported textile traders in domestic markets. The strengthening of SMEs' entrepreneurship through trademarks utilization for reputation building and development of branding infratrcture 
is a part of proposed action to prepare Indonesia's batik SMEs cope with freetrade market in the next 2015. To assess such utilization, the study will look upon the current condition of registered trademarks owned by batik SMEs.

\section{A. Current Conditions of Trademark Utilizations in Yogyakarta, Pekalongan, and Solo}

Pre-eliminary research on batik SMEs in Thamrin City, Jakarta, indicates that they have already used trademarks as a name for their stores, and sometimes also as label attached to the products. The SMEs in Thamrin City come from various areas of batik trading centers in Java, namely Yogyakarta, Pekalongan, and Solo. Therefore, the data obtained through such pre-eliminary activities can provide initial background for trademark utilizations in those three areas. As aforementioned, the SMEs already have their own trademarks, yet only few of them who have formally registered the trademarks to DGIPR Indonesia. Similar condition is also found in Yogyakarta city and Giriloyo, Bantul, especially the SMEs who only have micro or small business scales. These micro or small SMEs usually are those of family business-based with workshops at their houses, or kinships of craftswomen/craftsmen, with or without (usually) small showrooms. Furthermore, the names they usually use as trademarks are sometimes originally functioned as trade names. Therefore, they did not create the names specifically to meet the criteria of a good trademark, such as having distinguishing signs or distinctive names. The products they made usually are also based on other SMEs', such as traders or showrooms, orders in which the trademark labels of those SMEs will be attached to the products as per their requests. In this case, the trademarks that the micro or small SMEs have cannot effectively be utilized in their products, and the trademarks only function as trade names by which other SMEs can recognize them among other similar micro or small SMEs. This is sometimes unfortunate, since the micro or small business can actually produce a good quality and characterized products; and without the use of their own labels, in which other SMEs then put their labels on the products, the one getting advantage from the product quality (and reputation), are those SMEs who made the orders, and not the micro/small SMEs producing batik.

Small SMEs in Kauman, Pekalongan also have similar conditions. They have already used certain names for their workshops and/or showrooms, yet many of them have not formally registered the trademarks. Many of them also sometimes receive orders of batik products from other SMEs, in which such ordering SMEs then will put their own labels to the products. The trademarks or tradenames of Kauman's SMEs also hardly use distinctive names. Even so, those SMEs usually have already aware on the need of trademarks registration and prohibitions on the use of others' trademarks untruthfully or in bad faith. The reason of this unregistered trademarks are mainly because of the SMEs reluctance in government's complicated and costly bureaucracy in regards to the trademarks registrations. Another reason is because they have not considered trademarks as essential factor for the products' sales. Their main objectives are basically economic income, and batik orders from other SMEs are being considered as one important source of income, even though it brings implication of their unability to use their own labels on the products. Moreover, they also think that use of trademark and its registration cannot guarantee 
any improvement to the sales, and that they feel that consumers buy batik products based on the choices of motifs/patterns, and not solely because of such batik's trademarks. For the SMEs who only have small business, they do not have sufficient money to open a dedicated showroom, including to promote and advertise their own batik trademarks. Further, the production activities have already taken almost all their time and energy, so that they hardly can manage or administer technical things, such as trademarks registration and promotion, or showroom management, unless they have paid workers. Again, to reach that level, they need to have sufficient money or capital. Batik SMEs in Laweyan, Solo, may have better awareness and understanding on the importance of trademarks utilization and registration. Many of the SMEs in Laweyan have alredy registered their trademarks. As a family business having both workshop and showroom with a particular trademark, they have a vision towards enterpreneurship and development of business, including quality control of the products. For instance, the SMEs have applied the national standard for batik products (Standar Nasional Indonesia - Indonesian National Standard).

\section{B. Potentials for Collective Trademarks}

Prior art research regarding IPR utilization by SMEs took case study of pearl craftsmen/craftswomen in Amuntai and Lombok, West Nusa Tenggara (Nusa Tenggara Barat) province. The research was conducted through a quantitative method with surveys upon the perspectives of those SMEs toward IPR legal system. According to the research, it was found out that the there is a living value among the craftsmen/craftswomen that indicates a communal characteristic, either in regards to the sharing of knowledge in making of pearl handicrafts, or imitation of crafts' designs, which are not considered as a legal problem for them. It was also found that the craftsmen/craftswomen are gathered in a community, who live in the same area and be known as a community of pearl handicrafts producers ${ }^{22}$. Furthermore, another research focusing on Indonesian ethnic societies by Hokky Situngkir, titled 'Evolutionary Clustering in Indonesian Etchnic Textile Motifs,' also describes the phenomena of communalities, and each of the community residing at particular area has a distinguishing characteristic of textile motifs. For instance, motifs of batik cloths in Java will be different with motifs of songket cloth from Sumatra. This relates to what Tulus Tambunan mentions in his book regarding SMEs in Indonesia; that usually SMEs producing similar goods are situated nearby to each other, or as also called as 'cluster.' Each local area may be famous for different cluster of products of craftsmanships ${ }^{23}$. In this context, cluster of SMEs in particular area of Sumatra will be known as the center for songket cloth production, as well as how Giriloyo, Kauman, or Laweyan in the three different areas are known to be clusters for batik productions. Having strong historical background of batik culture as a community of traders, Laweyan SMEs have a profound awareness on their identities and cultural traditions in batik creation. As a community, they also keep developing the community's batik culture and business, through formation of community's organization.

22 See SARDJONO, Intellectual Property Utilization, see note 9.

${ }^{23}$ Tulus Tambunan, Usaha Mikro Kecil dan Menengah di Indonesia - Isu-isu Penting (Micro, Small, and Medium Enterprises in Indonesia - Important Issues), (2012). 
Laweyan SMEs also consider themselves as having different characteristic and quality compared with batik SMEs from other areas. Batik craftswomen/ craftsmen in Giriloyo, Bantul, also gather in a community's organization and they keep preserving their identity as a distinguished village's community who produce batik tulis (written batik) and batik cap (stamped batik) or a combination of both.

The living value of communalities between such batik SMEs, rise potentials of collective trademarks development. According to the Law No. 15 Year 2001 concerning Trademarks ("Trademark Law"), collective marks/ trademarks are the mark that is being used for certain products and/or services having similar characteristics which are being traded by group of people or entities altogether. In this context, the SMEs residing in a particular cluster and/or gathered in a community with similar craftsmanship's products may utilize and develop their own collective trademarks. The collective trademarks are usually used by the members of group, or association/ organization which involve in the trading activities of such similar products or services. In order to use the trademark together, the members need to have an agreed terms and conditions, or rules, regarding the use of the trademark, such as only for particular types of products or services with certain qualities or characteristics. This set of rules are also important to maintain the quality and characteristic that the products should have, so that if in any case, any member cannot comply with the rules, it's right to use the collective mark may be revoked. Furthermore, if there are other SMEs outside the association/ organization who wants to become the member of it, and produce the goods which use the collective mark, such new SMEs then need to comply with the collective trademark rules too.

The association or organization in where the members are gathered, usually acts as the one who facilitate the making of such agreed rules, as well as taking roles in monitoring the use of collective trademark, so that the member SMEs' products or services which use the mark will continuously comply with the agreed rules. Article 50 paragraph (3) of the Trademark Law stipulates that collective trademark rules ${ }^{24}$ should at least regulate:

a. Characteristic, general features or certain qualities of the products or services being produced and traded;

b. Effective monitoring on the use of trademark, and

c. Penalty for the use of trademark which infringes the collective trademark rules.

In Indonesia, the association or organization can apply for collective trademark registration to DGIPR on behalf of its members. For such registration, the association then needs to list all of its members who will be using the collective mark. The members of the association or organization itself are the SMEs who produce and/or engage in the products' trading activities, so the association or organization is not an independent one, in the sense that those who actively take roles as the managers of association/ organization's are some of the SMEs themselves, who will also be using the collective mark ${ }^{25}$. The collective trademark system has advantages in regards

${ }^{24}$ The World Intellectual Property Organization (WIPO) refers the collective trademark rules as "The Regulation Concerning the Use of Collective Mark".

${ }^{25}$ See Firth, Alison, et.al., Trade Marks, Law and Practice - Third Edition (Bristol: Jordan Publishing 
to the cost of trademark registration and marketing activities. If the SMEs file the application of trademark registration by itself, the cost will be higher and may discourage them to administer the registration. However, if it is in the form of collective mark they will bear all the cost of registration's application altogether. As an individual SME, difficulties they have in promoting their brands and marketing of products to distributors or consumers can also be tackled together if they gather as a collective group with the same trademark ${ }^{26}$. One necessary requirement to achieve such collectivity is of course, they have to produce goods or services which have similar characteristics with each other ${ }^{27}$.

The research findings in batik centers of the three areas indicate quite similar condition. The batik craftswomen/craftsmen communities in the three areas have already gathered under an organization or cooperative of batik SMEs. In Giriloyo, at the lower level, the craftswomen/craftsmen have gathered in a kinship, so that there can be found several kinships in the area. Those kinships then gather under a cooperative which manages other batik communities in wider areas around Bantul aside from Giriloyo. In Kauman, Pekalongan, the community has also gathered under the village's society organization. The same also in Laweyan, where the SMEs gather in a organization forum for development of Laweyan as a batik village. Aside from using their own (if any) individual (registered or non-registered) trademarks or trade names, they can also use a collective trademark as a community of batik producers with certain characters or qualities organized under their own cooperative/organization/forum. As an organization or kinship, they can develop the necessary infrastructure of products' branding and marketing as well as maintaining the quality standards. For instance, a kindship in Giriloyo may develop a collective trademark for their traditional batik tulis products which use nature-based coloring materials. The character can either include the nuance of colors, or a distinguishable shape in the products' motifs. Another example, Laweyan batik community can also construct their own standards on batik products' characters and quality which can distinguish them from other batik products of other areas. To attach the collective mark into their products, aside from mark labels, they can also create a specific batik shape or motif as the logo which then be stamped or painted (using the canting and hotwax) in all of their products. Through these methods of utilizing the collective trademark, the consumers then can get information and recognize the batik products which come from SMEs in certain areas, with its own character and quality. ${ }^{28}$

Limited, 2012), $241-242$

${ }^{26}$ See Intellectual Property for Business Series Number 1", http://www.wipo.int/export/sites/ www/sme/en/documents/guides/translation/making_a mark indo.pdf, (visited July 4th, 2013).

${ }^{27}$ One objective of collective trademark system is to simplify the registration of individual applications. If for example, 10 companies produce goods with similar characteristics, then they can apply one trademark registration altogether to be used by all of them. See Harahap, M. Yahya, Tinjauan Merek Secara Umum dan Hukum Merek di Indonesia Berdasarkan Undang-Undang No. 19 Tahun 1992 (Legal Study on Trademark Law in Indonesia Based on the Law No. 19 Year 1992), (Bandung: Citra Aditya Bakti, 1996), 604.

${ }_{28}$ However, collective trademark should be differentiated with Geographical Indications. The collective trademark indicates certain SMEs as coming from particular community, group, or organization, while geographical indications indicate certain products as coming from certain area based on particular geographical (human or nature) factors that influence the quality of such products. git should be differentiated with Geographical Indications. 


\section{The Program of Batikmark for Batik Indonesia}

Vast amount of imported 'batik' spreading in Indonesia's domestic market has raised various reactions, which mainly concerning the protection of Batik Indonesia's traditional and commercial value. The consumers, who cannot differentiate between the imported 'batik', (which cannot be considered as batik of Indonesia), and the real batik of Indonesia, misleadingly value the two products culturally as the same. Later, the imported 'batik', which technically called as 'textilles with batik patterns/motif' influence the development of printed batik, or batik printing, by Indonesia's batik SMEs. Even though they have also begun to produce and sell batik printing, they still consider the traditional batik made with canting and hot-wax (malam) with hand-dyed coloring process and such, as the real batik of Indonesia. The issue remains is how the consumers then can recognize and choose between the traditional batik and batik printing, especially when they actually want to buy the real batik of Indonesia. The SMEs generally also mentioned that each type of batik has its own market or consumers. This means that it is on the nature of preference of the consumers' itself that he/she will not choose batik printing over the real traditional batik of Indonesia.The simplest method to differentiate batik printing with Batik Indonesia is through the observation of its price. If the price is astoundingly cheap, while the product is considerably good, then it can surely be stated as batik printing. However, the method will not work if the trader itself sells the product in bad faith; in the sense that, they sell the products using the standard prices of traditional batik (which are higher than batik printing), yet the products sold are actually batik printing. In this case, certainly their motivations are of course to maximize the profit.

Batik Indonesia's products are more expensive, especially batik tulis, because of their complicated production's technique and craftmanships, including in the selections of materials used, such as the use of specific cloth (mori), or coloring materials. The resulted batik products not only have fine quality, but also uniqueness and authenticity, depending on the creativity and skills of the craftswomen/craftsmen. Even though for instance, the patterns/ motifs between Batik Indonesia and batik printing are the same, they went through a completely different process, in which batik printing is made only through a printing of Batik Indonesia's patterns/motifs into the cloths using machines. Batik printing's patterns/motifs are not created through a handmade painting or stamping with canting and hot-wax, and the coloring process is not through a hand-dyeing method. All the patterns/motifs and the colors, are printed into the cloth. However, from the eyes of an amateur consumer, the distinguishing quality can hardly be seen. Only consumers with sufficient background or familiarity with batik culture and technique can easily recognize which one is Batik Indonesia and which one is batik printing. Therefore, in order to prevent unfair and bad faith-traders, the Ministry of Industrial Republic of Indonesia issued a regulation concerning the use of Batikmark to indicate Batik Indonesia's products.

The regulation of Batikmark was issued in 2007 in the form of Minister of Industrial's Regulation No: 74/M-IND/PER/9/2007 concerning the Use of Batikmark "Batik Indonesia" on Indonesian-made Batik ("Batikmark Regulation"). This Batikmark program was launched to provide a quality assurance for traditional batik products of Indonesia, including as an 
identification instrument of such traditional batik products among the other similar 'batik' products in the market. Batik products which can use Batikmark labels are only those of traditional ones: batik tulis, batik cap, or a combination of both, which process involves the application of hot-wax (malam) as a resist and hand-dyed coloring. In order to use the Batikmark, then, batik SMEs need to obtain Batikmark certificate, which can be granted after fulfilling the administrative and substantive requirements. In this respect, products of batik printing cannot be certified with Batikmark. The certification is given only to the SMEs who produce batik tulis and batik cap products under certain requirements.

According to the Batikmark Regulation, in order to obtain Batikmark certification, batik SMEs need to fulfill these following requirements:

i. The SMEs have registered, or have applied for registration of, their trademarks;

ii. The batik products have certain standard of qualities referring the Indonesian National Standard (Standar Nasional Indonesia), such as antifaded colors and rub-resist, and

iii. The batik products possess the characteristics of batik tulis, batik cap, or a combination of both, also, referring to the Indonesian National Standard (Standar Nasional Indonesia).

The institution having authorities to receive Batikmark application, conducting assessment, and granting of certification, is Balai Besar Kerajinan dan Batik ("Balai Batik") residing in Yogyakarta. According to Bachtiar Totosantoso from Balai Batik, the institution receives and proceeds applications from all areas in Indonesia. To this date, there have been approximately 109 SMEs who have obtained Batikmark certification ${ }^{29}$. The SMEs certified then can use Batikmark labels in their products according to its type: gold for batik tulis, white for batik cap, and silver for a combination of both.

\section{Batikmark Labels}

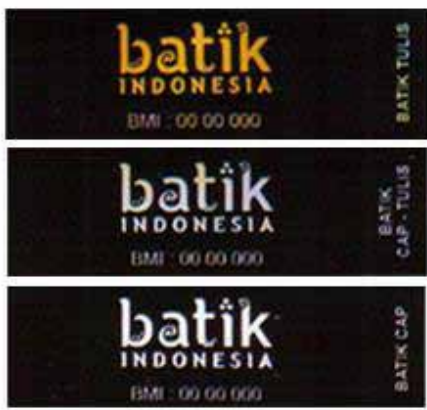

Source: http://prosesbatik.blogspot.com/2010/11/batik-mark-batik-indonesia.html

${ }^{29}$ See http://batik.go.id/batik/index.php/page/show/sertifikasi batik mark. 
Among the benefits of Batikmark certification is that, it can add commercial value to the products, since the quality is assured. The consumers can also identify the products of Batik Indonesia by seeing the labels, so that they will not mistakenly think batik printing as Batik Indonesia, either it is imported, or produced by local SMEs. Through such labels, it is expected that the consumers' awareness upon batik culture will increase, and they can differentiate between traditional batik of Indonesia and batik printing. In such a way, products of Batik Indonesia may have stronger position to compete with batik printing in batik trading markets, since the label can help the consumers recognize them. The choice is now at the consumers' hands, whether they want to buy the real batik, traditional batik of Indonesia (batik tulis, batik cap, or a combination of both), or batik printing products.

Although seemingly functioned as a mark indicating the type of batik, that mark is different with a trademark, because it only shows that the product has been certified with certain quality. It cannot indicate the producer/manufacturer, or the SMEs who produce the batik products. In this respect, Batikmark is having similar characteristic with certification mark. Certification mark is given in accordance with the fulfillment of the required standards. Therefore, basically certification mark can be granted to anyone, any SMEs, and it is not limited only for members of certain group or association. As long as the SMEs fulfill the required standards, they can be granted for certification mark ${ }^{30}$. The certification mark is granted by an authorized institution, independent from the SMEs/companies' groups/ associations. If the collective mark indicating from which community the SMEs are coming from, the certification mark indicates the quality of their products that they have been going through particular certification process ${ }^{31}$. The products having certification's standards are not necessarily better than those which are not certified. The certification only serves as an assurance that the products have particular standards of quality. This quality, then, can also be varied among the other SMEs who have not been ceritified. It is possible that they have better quality of products than those of the standarded ones.

In this context, Batikmark helps indicating the original product of Batik Indonesia from the local SMEs, as well as maintaining the products'standarded quality. In order to know which SMEs producing the batik, or from which community/group, trademarks (either individually or collectively) are still needed. Among the disdadvantages of this certification is it requires another administrative and assessment process for the SMEs according to certain standards. If there are SMEs who actually produce batik through the traditional craftsmanship, namely the use of malam, canting, and handdyed coloring, however applying different standards with Batikmark, such products then may not be considered as Batik Indonesia while culturally they are; as part of intangible cultural herritage ${ }^{32}$. Other problem arises when the SMEs have already applied and obtained the Indonesian National Standard (Standar Nasional Indonesia - SNI) for batik products ${ }^{33}$, which is determine by

\footnotetext{
${ }^{30}$ See see note 26 .

${ }^{31}$ For instance, the certification is regarding the characteristics, materials, or manufacturing process of the products.

${ }^{32}$ Referring to UNESCO, see see note 2.

${ }^{33}$ See http://www.suaramerdeka.com/v1/index.php/read/news/2013/09/03/170629/PerajinBatik-Laweyan-Raih-SNI (visited November 20th, 2013).
} 
the National Standardization Agency (Badan Standardisasi Nasional - BSN) ${ }^{34}$. The question is, whether they need to pass the products' examination (again) during the application process of Batikmark, since the quality standard that Batikmark's requires is as based on the SNI. Batikmark actual function is to indicate the types of Batik Indonesia and provide the product's quality assurance as differed with non-Batik Indonesia (i.e. Batik Printing). The SNI, in other side, also serves as the certification for batik products' quality assurance, in regards to its type of mori or the quality of the materials' used. If Batikmark is a certification of Batik Indonesia's types and characteristics, SNI is the certification for the products' quality ${ }^{35}$.

It is important to note that Batikmarks is not contradictory with SNI, rather, the examination on products use the quality standard of SNI as the reference. Thus, if batik SMEs apply for Batikmark certification, automatically its products obtain two assurances: the assurance as products of Batik Indonesia, and the assurance on the quality of products. The SNI's administrative fee is IDR $10,000,000$ (or around USD 1000) per type of product, while Batikmark's administrative and examination fee is around IDR $1,700,000$ (or around USD 170). This means that it could be more efficient to apply for Batikmark certification, rather than applying for the SNI then applying Batikmark, or solely the SNI. If the SMEs apply for both certifications, then they have to pay at least USD 1,170 per type of product. As an example, the owners of Batik SMEs at Laweyan, Solo shared their resistance on applying for Batikmark certification since they have already applied and obtained the SNI. If then they also apply for Batikmark, then they will have to spend another cost for Batikmark certification.

Furthermore, the SMEs, particularly in Kauman, Pekalongan, also challenge the implementation of Batikmark ceritifcation. According to their opinions, the implementation of Batikmark creates another burden for the SMEs, either in regards to the costs, or the administrative bureaucray. In their perspectives, the obligation to use labels as indication of the product's type should be imposed to the traders or SMEs who produce and sell batik printing, including the imported ones, so that all batik printing products can be recognized by the consumers in the market. Regardless such positive or negative attitude towards the certification, there are also SMEs who can get benefits from the use of Batikmark certification, or the SNI, especially when they export the products abroad, or simply by the fact that there are segments of consumers who prefer to buy such certified products. To this date, compared with the total numbers of batik SMEs in Indonesia, only small numbers have registered for Batikmark certification, even though the Ministry of Industry has provided financial subsidy for the administration of Batikmark. This probably because of the requirement of SNI's standards, which not all SMEs can fulfill, and that they need to apply for trademark registration to DGIPR first, while in fact many of them have not applied for trademark's registrations ${ }^{\square}$.

${ }^{34}$ The SNI certification is issued by the Products Certification Agency (Lembaga Sertifikasi Produk) based on the standards determined by BSN.

35 See http://www.tempo.co/read/news/2013/09/03/090509886/SNI-Batik-Belum-BanyakDimanfaatkan-Pengusaha (visited November 20th, 2013). 


\section{Conclusion}

In order to support and help batik SMEs competing in free-trade markets, the collective trademark system is proposed. The individual trademark system has not been successful to support the SMEs batik's business, considering their reluctance to administer the registration, and that its registration cannot assure the improvement of their business and profits they can receive. To build the brand's reputation individually is also another burdening task for the SMEs. Furthermore, the Batikmark certification which is aimed to indicate Batik Indonesia as different with imported 'batik', has also not been used effectively by the SMEs. Many of them consider it as another bureaucratic process just like the registration of trademarks which are costly and time consuming. The collective trademarks system may address the issue of administrative and costs burden that the SMEs have to deal with if the apply for trademark registration individually. The fact that batik SMEs gather in a organization or kinships can be optimized to support their business through registration of collective trademark and building of brand infrastructure with local community's standardization and collective batik labelling. In this respect, they can construct their local quality and characteristic, consent on them in a set of agreed rules, and use collective labeling to indicate their community's products. Legally, they can register such collective standardization and labeling through collective trademark registration. By such a way, they can cooperate as a community to maintain their quality of products, and local identity altogether according to their respective needs.

\section{Bibliography}

\section{Books}

Elliot, Inger McCabe. 2004. Batik - Fabled Cloth of Java (Periplus Editions (HK) Ltd.). Firth, Alison, et.al. 2012. Trade Marks, Law and Practice - Third Edition (Bristol: Jordan Publishing Limited).

Hamzuri. 1989. Batik Klasik (Djambatan).

Katalog Batik Khas Yogyakarta. Kantor Wilayah Departemen Perindustrian Propinsi Daerah Istimewa Yogyakarta (Yogyakarta: Proyek Pengembangan Industri Kecil dan Menengah (PIKM) Propinsi D.I. Yogyakarta, 1996).

Lin, Lee Chor. 2007. Batik - Creating an Identity (National Museum of Singapore).

Nomination for Inscription on the Representative List in 2009 (Reference No. 00170). Convention for the Safeguarding of the Intangible Cultural Heritage, Intergovernmental Committee for the Safeguarding of the Intangible Cultural Heritage, Fourth Session (Abu Dhabi, United Arab Emirates: UNESCO, 2009).

Sekimoto, Teruo et.al.. 2003. Handicrafts and Socio-Cultural Change: A Study of Batik Making in Cirebon and Pekalongan (Centre for Japanese Studies, University of Indonesia).

Widyawati, Naniek. 2004. Settlement of Batik Enterpreneurs in Surakarta (Yogyakarta: Gadjah Mada University Press).

Wulandari, Ari. 2011. Batik Nusantara: Makna Filosofis, Cara Pembuatan, dan Industri Batik, Edisi 1 (Yogyakarta: ANDI). 


\section{Journal and Thesis}

Sardjono, Agus. Titik Singgung Perlindungan HKI: Hak Cipta, Merek, dan Desain Industri, Jurnal Hak Kekayaan Intelektual Vol. 1 No. 1, 2012.

Sari, Dyan Ratna. Ekses Pasal 10 UU No. 19 Tahun 2002 tentang Hak Cipta Terkait Pemanfaatan Motif Batik Surakarta. Skripsi, Fakultas Hukum Universitas Indonesia, 2013.

\section{Legal Documents}

Menteri Perindustrian Republik Indonesia. Peraturan Menteri Perindustrian Republik Indonesia Nomor: 74/M-IND/PER/9/2007 tentang Penggunaan Batikmark "batik Indonesia" pada Batik Buatan Indonesia.

Republik Indonesia. Undang-Undang Nomor 19 Tahun 2012 tentang Hak Cipta, Lembaran Negara Republik Indonesia Nomor 85 Tahun 2002, Tambahan Lembaran Negara Nomor 4220.

\section{Internet Resources}

Balai Besar Kerajinan dan Batik Yogyakarta, http://www.batik.go.id.

Batik Tulis, http://www.kampoenglaweyan.com, diakses pada 17 Juli 2013.

Batik dan Nilai Heritage, http://www.batikyogyakarta.com/category/sejarah/, diakses pada 9 Juli 2013.

Batikmark Sepi Peminat, Dinas Perindustrian, Perdagangan, Koperasi, dan UMKM Kota Pekalongan, http://perindagkop.pekalongankota.go.id/, diakses pada 18 Juli 2013.

Busana Batik di Lingkungan Kraton, http://www.kerajaannusantara.com/id/ surakarta-hadiningrat/busana-batik-keraton, diakses pada 19 Juli 2013.

Geografi, www.pekalongankota.go.id, diakses pada 17 Juli 2013.

Kampung Batik Kauman, http://surakarta.go.id/konten/kampung-batik-kauman.

Pembangunan Daerah Bidang Koperasi dan Usaha Kecil Menengah, Website Pemerintah Kota Pekalongan, http://www.pekalongankota.go.id, diakses pada 17 Juli 2013.

Sejarah - Kampoeng Laweyan, http://www.kampoenglaweyan.com, diakses pada 15 Juli 2013.

Sejarah, http://www.pemda-diy.go.id/, diakses pada 17 Juli 2013.

Sejarah Singkat, Website Pemerintah Kota Pekalongan, http://www.pekalongankota. go.id, diakses pada 17 Juli 2013.

Selayang Pandang, http://surakarta.go.id/konten/selayang-pandang.

Sentra Industri, Dinas Perindustrian, Perdagangan, Koperasi, dan UMKM Kota Pekalongan, http://perindagkop.pekalongankota.go.id/, diakses pada 17 Juli 2013.

Steelyana, Evi, Batik, A Beautiful Cultural Heritage that Preserve Culture and Support Economic Development in Indonesia (Bina Nusantara University), diakses melalui www.ssrn.com, pada 9 Juli 2013, hlm. 6.

Tentang Batik, www.museumbatik.com, diakses pada 9 Juli 2013. 